\section{Competitive Market Analysis: Chestnut Producers}

\author{
Michael A. Gold ${ }^{1}$, Mihaela M. Cernusca, and Larry D. Godsey
}

Additional Index words. Castanea spp., marketing, market survey, Porter five forces model, value chain

SUMMARY. In 2004, a nationwide survey of chestnut (Castanea spp.) producers in the United States was conducted. Results show that the U.S. chestnut industry is in its infancy. The majority of chestnut producers have been in business less than 10 years and are just beginning to produce commercially. Volume of production is low $(<1.5$ million $\mathrm{lb})$. U.S. chestnut producers are mainly part-timers or hobbyists with small, manually harvested operations. The majority of respondents sell fresh chestnuts. Demand exceeds supply, and prices often exceed $\$ 3.50 / \mathrm{lb}$. Barriers to success in the chestnut business include the lack of information for producers, retailers, and consumers, 5- to 10-year time lag to get a return on investment, and shortage of available chestnut nursery stock of commercial cultivars. There are also concerns related to pest and disease control and market uncertainties. Lengthy quarantines for cultivars from other countries and lack of chemicals registered for use with chestnuts can also be considered barriers to success. Chestnut grower associations, universities, and state and federal agencies must join their efforts to fund and support chestnut research and industry development.

$\mathrm{T}$ This paper, focused on the U.S. chestnut market, is one of a series of papers intent on developing a detailed understanding of specific agroforestry markets (Gold et al., 2004a, 2005a). Widespread adoption of agroforestry in North America is lagging. This is due, in part, to the understandable reluctance of risk-averse producers to establish agroforestry practices in the absence of readily available market information. Market knowledge is a key ingredient in the success of profitable agroforestry enterprises that produce commercially valuable specialty products (Gold et al., 2004a).

Edible chestnuts are a tree crop of increasing interest worldwide (Gold et al., 2004b). Until the near extinction of the american chestnut (Castanea dentata) forest from chestnut blight (1904-50; caused by the fungus Cryphonectria parasitica), american chestnuts were sold by the railroad car

$\overline{\text { University of Missouri Center for Agroforestry, } 203}$ ABNR Building, Columbia, MO 65211

Acknowledgements. This work was funded through the University of Missouri Center for Agroforestry under cooperative agreement AG-02100251 with the USDA ARS Dale Bumpers, Small Farms Research Center, Boonville, Ark. The results presented are the sole responsibility of the P.I. and/or MU and may not represent the policies or positions of the ARS.

${ }^{1}$ To whom reprint requests should be addressed: phone: 573-884-1448; fax: 573-882-1977; e-mail: goldm@missouri.edu in the cities of the eastern U.S. With the demise of the american chestnut forests, this food was essentially lost from the American diet for a couple of generations (Wahl, 2002a). Today, chestnuts are experiencing a surge in consumer popularity in many European countries, Australia, New Zealand, and the U.S. (Kelley and Behe, 2002), and an increase in production in Asia [Bodet et al., 2001; U.S. Department of Agriculture (USDA), 2005]. World chestnut exports in 2003 were $106,000 \mathrm{t}$. According to the Food and Agriculture Organization of the United Nations (FAO) statistical database, the U.S. imported 4500 tin 2003 and 5400 $\mathrm{t}$ in 2004 (FAO, 2005). In response to this trend, and to the fact that the U.S. consumer has an increased interest in both new and healthy foods (Blisard et al., 2002), efforts are in progress to increase chestnut production and consumption throughout the U.S. Over the past 20 years, little research has been conducted concerning chestnut production and marketing (Gold et al., 2004b).
Commercial chestnut production in the U.S. is based more on trial and error than on coordinated research and scientific experimentation. To date, edible chestnut research initiated throughout the U.S. lacks effective collaboration, discussion, and exchange of current results and ideas. The nascent chestnut industry includes producers who are developing orchards in the midst of a paucity of solid scientific information regarding chestnut species and their long-term adaptability to specific sites in terms of climate or pests. Chestnut plantings contain a large amount of genetic diversity and/or interspecific hybrids, but few cultivars are available for purchase in commercial numbers.

Scattered efforts exist throughout the U.S. to develop domestic chestnut production based on chestnut species and cultivars from Europe or Asia. Fulbright (2002) and Hunt et al. (2005) reported on research and grower feedback on germplasm, horticultural aspects of growing trees for good nut production and harvest, and postharvest treatment and marketing of chestnuts, and provided guidelines for commercial chestnut cultivation in midwestern states to new or potential chestnut orchardists. Southeast Iowa Nut Growers Association published the Chestnut Growers' Primer to provide chestnut producers with basic background information for successful chestnut production (Wahl, 2002b).

Research efforts are currently under way at the University of Missouri Center of Agroforestry (UMCA) to identify improved cultivars of chinese chestnut (C.mollissima) and to provide guidance to growers in Missouri (Hunt et al., 2005). Along with production research, it is necessary to develop the domestic market by introducing the chestnut as a food crop to a new generation of U.S. consumers. Consumer preference marketing studies were conducted in 2003 and 2004. The 2003 study assessing consumer preferences for chestnuts, pecans (Carya illinoensis), and eastern black walnuts (Juglans nigra) was continued in 2004, focused

\begin{tabular}{lllc}
\hline $\begin{array}{l}\text { Units } \\
\text { To convert U.S. to SI, } \\
\text { multiply by }\end{array}$ & U.S. unit & SI unit & $\begin{array}{l}\text { To convert SI to U.S., } \\
\text { multiply by }\end{array}$ \\
\hline 0.4047 & $\mathrm{acre}(\mathrm{s})$ & $\mathrm{ha}$ & 2.4711 \\
0.4536 & $\mathrm{lb}$ & $\mathrm{kg}$ & 2.2046 \\
1.6093 & $\operatorname{mile}(\mathrm{s})$ & $\mathrm{km}$ & 0.6214 \\
0.9072 & $\operatorname{ton}(\mathrm{s})$ & $\mathrm{t}$ & 1.1023
\end{tabular}


solely on chestnuts. As in 2003 (Gold et al., 2004b), consumers surveyed in 2004 were unfamiliar with chestnuts; they were unaware of their healthful properties, in what form and where to buy them, or how to prepare them. Survey participants preferred to buy roasted or fresh chestnuts from grocery stores or farmers markets. Quality and nutrition-diet-health were perceived as the most important attributes that influence the decision to purchase chestnuts in both the 2003 and 2004 studies (Gold et al., 2005b).

Following initial research into the consumer perspective, UMCA researchers are seeking to gain an indepth understanding of the chestnut marketplace. The objective of this study is to look at the U.S. chestnut industry from the producer's perspective and take into consideration all the forces that influence competition, based on Porter's five forces model (PFFM) (Porter, 1980). By understanding the forces, chestnut producers already in the market can find ways to react to these forces in their own interest and maintain or develop competitive advantages that will help them succeed in the industry. The study also provides valuable information to individuals looking to enter the marketplace, with chestnut production being either a potential alternative farm crop or an opportunity for people already in the orchard business to diversify into different markets.

\section{Materials and methods}

To analyze the chestnut market from the producer's perspective, a multiple-step research methodology was employed. First, chestnut producers all over U.S. were identified using information from the Internet (e.g., keyword searchers for businesses involved in all aspects of chestnut production, university websites that offered links to sources of chestnut products), chestnut grower associations (e.g., Chestnut Growers of America, Northern Nut Growers Association, The American Chestnut Foundation, Southeast Iowa Nut Growers Association), and university colleagues. A database of chestnut producers was developed.

Second, a questionnaire-based survey was developed. The survey contained specific questions for chestnut producers. A combination of yes/no, closed and open-ended questions were designed to collect general information about the market participants (i.e., type of chestnuts grown, activities performed, questions about utilization of brand name, advertising and publicity, size of production operation, degree of involvement in the production of chestnuts, type of production, management practices, and harvesting methods) and information specific to each of the Porter's five forces (Porter, 1980).

The PFFM looks at five areas of competition that market participants face. These areas include: barriers to entry, bargaining power of suppliers, bargaining power of buyers, threat of substitute products, and rivalry among existing firms. The influence of governmental policies on the market was added to the PFFM. By understanding the competitive forces within the chestnut industry, market opportunities and threats can be identified and successful strategies can be developed.

Questionnaires were mailed to all individuals identified in step one. Using a snowball approach (i.e., a question in each survey asked for names and contact information of other participants in the market; the newly identified individuals and businesses were added to the database and questionnaires were mailed to them), 250 questionnaires were mailed nationwide.

Using SPSS (SPSS Inc., Chicago), descriptive analysis was performed to analyze the data.

The focus of this paper is to describe the chestnut market from the producers' perspective. Additional research is under way to explore the value chain in more depth and describe the interactions between suppliers, producers, and sellers of chestnuts.

\section{Results and discussion}

Out of 250 questionnaires mailed, 90 were returned and analyzed (36\% response rate). Responses came from 15 states. The highest representation came from Michigan (21\%), followed by states on the west coast (Oregon = 16\%; California $=12 \%$; and Washington $=8 \%$ ).

\section{General information about survey respondents and the industry}

INVOLVEMENT IN CHESTNUT PRODUCTION. Based on survey responses, the industry is dominated by small-scale producers with minor commercial involvement in chestnut production (Table 1, Fig. 1). Out of all respondents, only $20 \%$ are full-time farmers and only one-quarter $(24 \%)$ of the full-time farmers consider chestnuts to be more than $50 \%$ of their farming operation. The majority $(53 \%)$ are part-time farmers and over half of this group deal with other crops or activities more than with chestnuts. Twenty-seven percent are hobbyists. With hobbyists, there is little focus on commercial production and profit and more interest in tinkering, experimentation, and pleasure.

LONGEVITY IN CHESTNUT PRODUCTION. The U.S. chestnut industry is young. The vast majority of producers (96\%) have been in the market less than 20 years and $64 \%$ less than 10 years (Fig. 2). Therefore, orchards are new, most just entering commercial production $(92 \%$ of respondents have trees under age 20 years and more than half under age 10). Commercial chestnut production begins between 5 and 10 years after establishment, depending on location, management, and other factors.

REVENUE GENERATED BY CHESTNUTS. The revenue generated by chestnuts in the industry is very low. An overwhelming majority of producers who responded to the survey $(96 \%)$ earn less than $\$ 25,000$ annually from

Table 1. Proportion of respondents' business represented by chestnuts for each category [farming is a full-time occupation $(\mathrm{N}=17)$, farming is a part-time occupation $(\mathrm{N}=43)$ and farming is a hobby $(\mathrm{N}=21)]$ as derived from a nationwide survey of U.S. chestnut producers.

\begin{tabular}{lccc}
\hline $\begin{array}{l}\text { Proportion of } \\
\text { respondents' business } \\
\text { represented by chestnuts }\end{array}$ & $\begin{array}{c}\text { Farming is a } \\
\text { full-time } \\
\text { occupation }\end{array}$ & $\begin{array}{c}\text { Farming is a } \\
\text { part-time } \\
\text { occupation }\end{array}$ & $\begin{array}{c}\text { Farming is a } \\
\text { hobby }\end{array}$ \\
\hline & - & & \\
$<25 \%$ & 65 & 40 & 81 \\
$25 \%$ to $50 \%$ & 12 & 16 & 5 \\
$50 \%$ to $75 \%$ & 6 & 16 & 5 \\
$75 \%$ to $100 \%$ & 6 & 12 & 5 \\
$100 \%$ & 12 & 16 & 5 \\
\hline
\end{tabular}


chestnut sales. Eighty percent earn less than $\$ 5000 ; 16 \%$ between $\$ 5000$ and $\$ 25,000 ; 2 \%$ between $\$ 25,000$ and $\$ 50,000$; and $2 \%$ between $\$ 50,000$ and $\$ 100,000$.

Production operation. The size of production operation mentioned most often was between 3 and 10 acres $(50 \%)$, followed by less than 3 acres $(26 \%)$. Fourteen percent have orchards between 11-20 acres; 7\% have $21-40$ acres; and $3 \%$ have over 40 acres. The most common density of trees is $51-100$ trees/acre $(52 \%$ of respondents). This is another sign that the orchards are relatively new. Research indicates that a maximum of 50 trees/acre is the optimal density for mature trees (Hunt et al., 2005).

There is interest in ecologically oriented production among the respondents. One question in the survey asked respondents to define their chestnut production as conventional, pesticide free, or certified organic. The results indicate that $46 \%$ of respondents produce chestnuts using conventional practices; $42 \%$ do not use pesticides; and $12 \%$ certified their production as organic.

Respondents indicated that they grow chestnuts from both seedlings and grafted cultivars. Seedlings derived from 'Colossal' [a european chestnut (C. sativa) $\mathrm{x}$ japanese chestnut ( $C$. crenata) hybrid] (Bassi and Craddock, 1999), 'Nevada', and unspecified cultivars native to China are the most common type grown by respondents. A specific question in the survey asked respondents to list the preferred three cultivars grown in their orchard (top sellers and the favorite, if different). Out of all cultivars that can be purchased in the U.S., 'Colossal' is by far the favorite. The preference for 'Colossal', especially in the eastern U.S., indicates a lack of testing, and unfamiliarity with and limited supply of other cultivars. In Michigan, yield data indicate that 'Colossal' has outperformed all other cultivars (Fulbright et al., 2003; Haak and Haak, 2003). The large number of producers that grow seedlings (26\% grow only seedlings, and $49 \%$, seedlings and cultivars) demonstrates that much of the current chestnut industry is not at a commercial stage. According to Fulbright (2002) and Hunt et al. (2005), a commercial industry cannot be established on seedlings. The uniformity and predictability required in

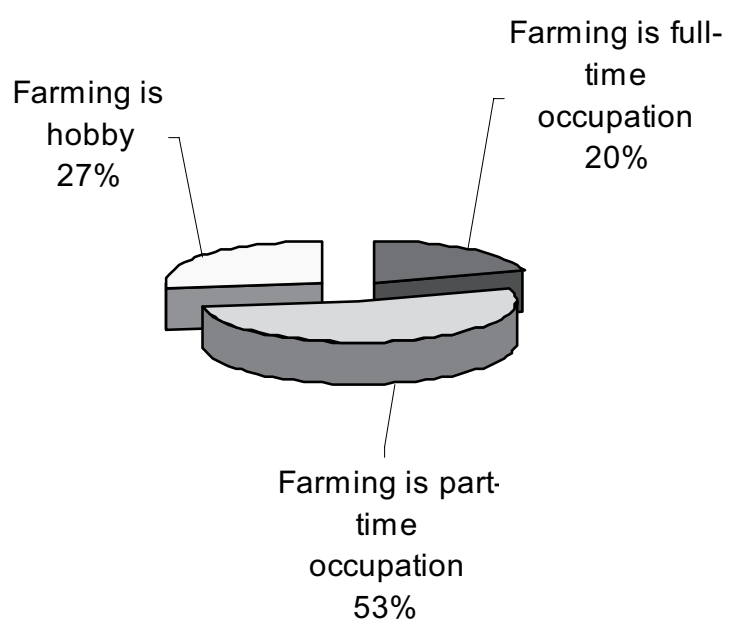

Fig. 1. Proportion of respondents $(\mathrm{N}=81)$ that are farmers as a full-time occupation, part-time occupation or hobby as derived from a nationwide survey of U.S. chestnut producers.

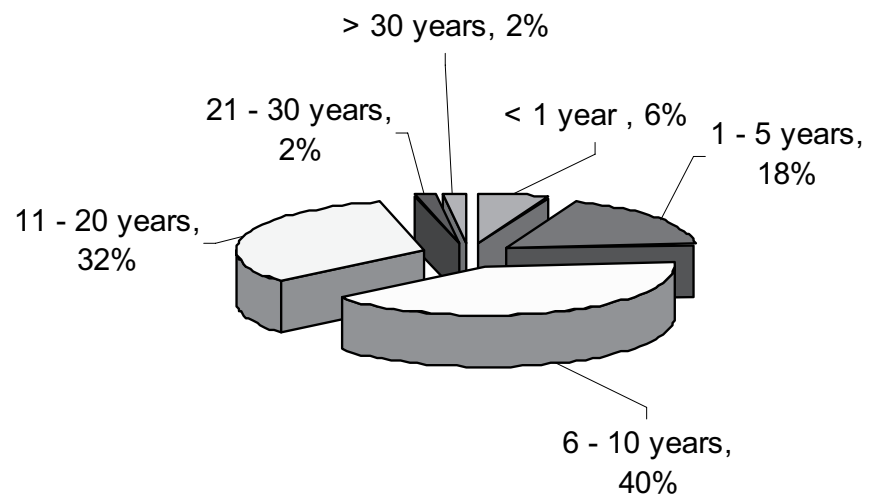

Fig. 2. Number of years participants in a nationwide survey of U.S. chestnut producers $(\mathrm{N}=90)$ have been growing and producing chestnuts.

a commercial orchard can be provided only by grafted cultivars.

The most common management practices used by respondents are mowing $(90 \%)$, pruning $(87 \%)$, and fertilization $(73 \%)$. Other practices mentioned include irrigation $(60 \%)$, herbicides $(48 \%)$, thinning $(41 \%)$, mulching $(37 \%)$, pesticides $(33 \%)$, and use of beneficial insects (4\%).

The majority of respondents (89\%) harvest manually, while $16 \%$ use machines to harvest chestnuts. Most respondents did not consider the investment in a harvesting machine as imperative because their chestnut production is not large enough to require mechanization. Some use machines adapted from equipment used for another nut crop (e.g., pecan).

Products sold. Most respondents produce and sell fresh chestnuts in bulk (77\%) or packaged (41\%). Some producers act as small nurseries and produce seedlings (21\%), grafted culti- vars (10\%), or chestnuts for seed $(20 \%)$. Nineteen percent of respondents sell processed products like chestnut flour, dried chestnut kernels, frozen chestnuts, chestnut honey, soup mix, and jam, jellies, or preserves, while 13\% sell chestnut-related products (e.g., roaster, mug, cap, knife) (Fig. 3).

Survey results indicate that processed chestnuts are a minor component of the overall U.S. chestnut market. In Asia, Australia, and Europe, chestnuts are used and sold in many different forms. Examples include peeled, roasted, ready-to-eat as a snack, candied as marron glacé, frozen, dried, canned, soup mix, jam, jellies, preserves, puree, and flour. Based on an Internet search of products produced and sold in other countries, many options for processed products were described in the survey. Few U.S. respondents were producing and selling the options presented. Survey results indicated that five respondents 
are diversified into more than two processed products. All of them are larger-scale producers (with more than $\$ 5000$ in annual gross sales exclusively from chestnuts).

While production is low, producers indicated that they had no difficulties selling all fresh chestnut production after harvest. For this reason, growers do not feel pushed to diversify into new products. As consumer demand for convenient, easy-to-prepare, and ready-to-eat chestnuts increases, some producers may develop supplementary activities in addition to selling fresh chestnuts. For example, in Australia, peeled, raw, or roasted frozen chestnuts are growing rapidly in popularity ( $\mathrm{J}$. Casey, personal communication). Additional processors may surface in the value chain as the diversity of products find their way to the market. Wider adoption of processed products would complement the value of fresh chestnuts, prolong shelf life, and provide a use for small chestnuts. Together with an increase in consumer awareness of chestnuts, processed products would help increase chestnut consumption beyond winter holidays to a healthy, year-round food.

BRANDING, ADVERTISING, PUBLICITY. Branding can help introduce and remind the customer of the unique value the product offers, build trust, and increase commitment and demand. This will result in a price premium, resulting in higher profitability (Brereton and Co., 2002).

Based on survey results, a relationship between the prices obtained for chestnuts and branding was found. Prices tend to be higher for businesses or individuals that sell chestnuts under a brand name.

One-third of respondents (33\%) recognize the advantage of developing a brand name. Respondents believe that a brand name would help the chestnut producer build trust and relationships with customers (26\%), encourage repeated purchase $(23 \%)$, increase awareness (21\%), and stimulate wordof-mouth advertising (18\%).

The remaining $67 \%$ of respondents do not consider it necessary to develop a brand name because either they are in a pre-production stage or sell low volumes, sell through a cooperative, or sell only in bulk. Of the producers who do not use a brand name (60 respondents), 33\% plan to create one in the future.

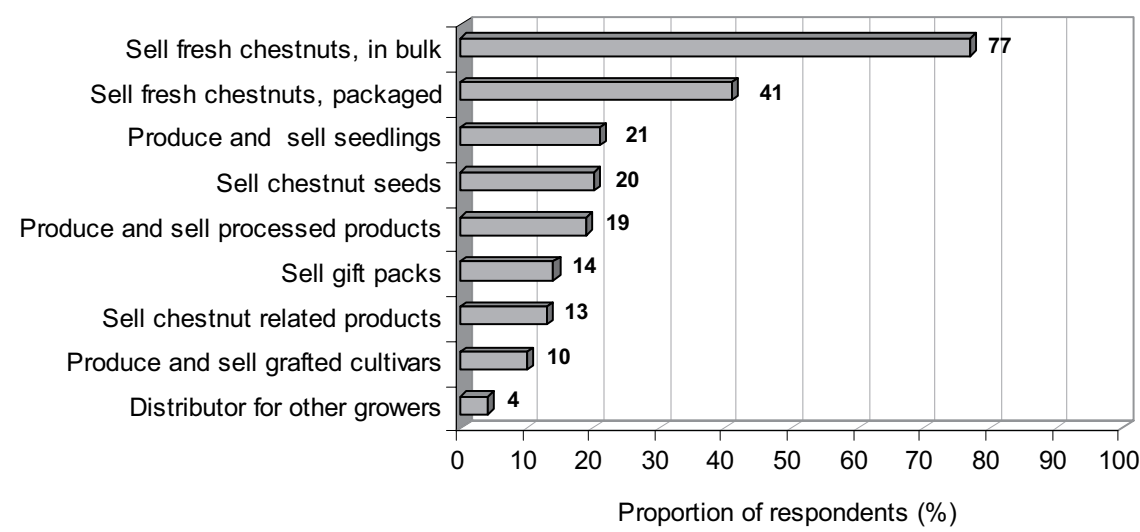

Fig. 3. Range of economic activities performed by participants in a nationwide survey of U.S. chestnut producers and the proportion of respondents involved in each activity $(\mathrm{N}=90)$. Percentages do not add to 100 because respondents had the option to select more than one choice.

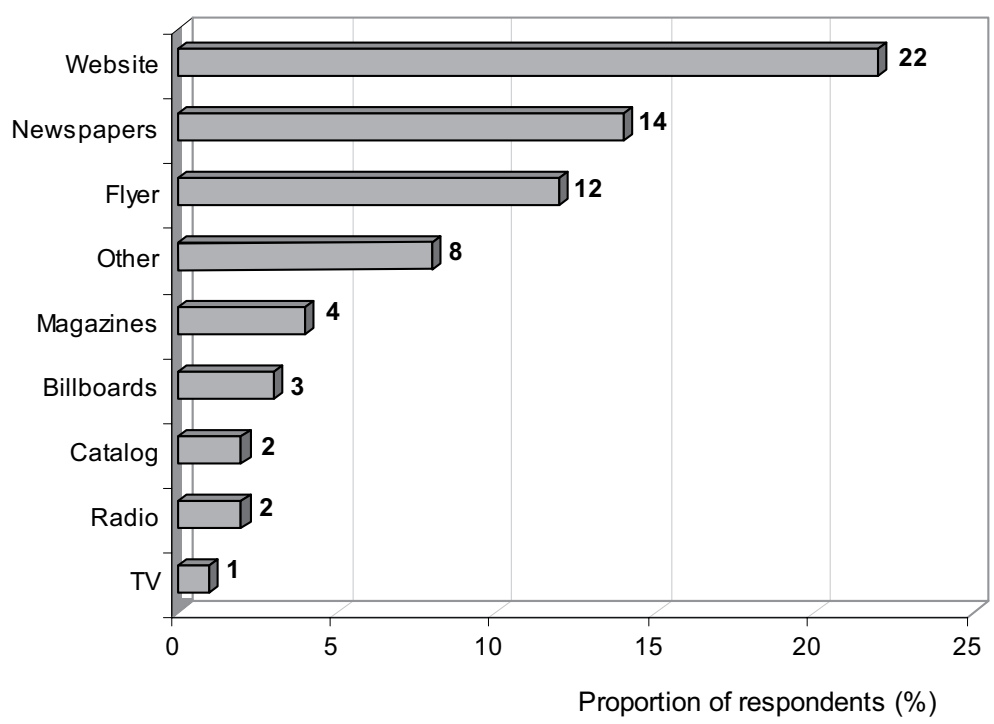

Fig. 4. Types of advertising used by $38 \%$ of the participants in a nationwide survey of U.S. chestnut producers and the proportion of respondents that use each type $(\mathrm{N}=90)$. Respondents had the option to select more than one choice.

Only 38\% of respondents use advertising to increase awareness of their chestnut products. Of that $38 \%$, the majority advertise on websites and in newspapers, flyers, magazines, or billboards (Fig. 4). Reasons mentioned most often for not advertising are low volume of production, the shift of responsibility for advertising toward the grower cooperative, and lack of time or resources.

Publicity is used more often than advertising by the respondents to increase awareness of their chestnuts and chestnut products. Methods used by respondents to generate publicity include offering free samples, issuing news releases, participating in festivals and fairs, sponsoring com- munity events, and collaborating with charities (Fig. 5). Demonstrations and tours offered to customers; talks given to clubs, colleges, and schools; expositions; publication of chestnut recipes; and referrals are other ways that respondents educate consumers, and were also mentioned as forms of publicity.

\section{Analysis of forces that drive competition in the chestnut market at the producer's level}

MARKeT FORCE 1: Threat OF NEW ENTRANTS (BARRIERS TO ENTRY). Barriers to entry inhibit new firms from entering the market, thus maintaining a level of profit for those already in the industry. Typical barriers to entry 


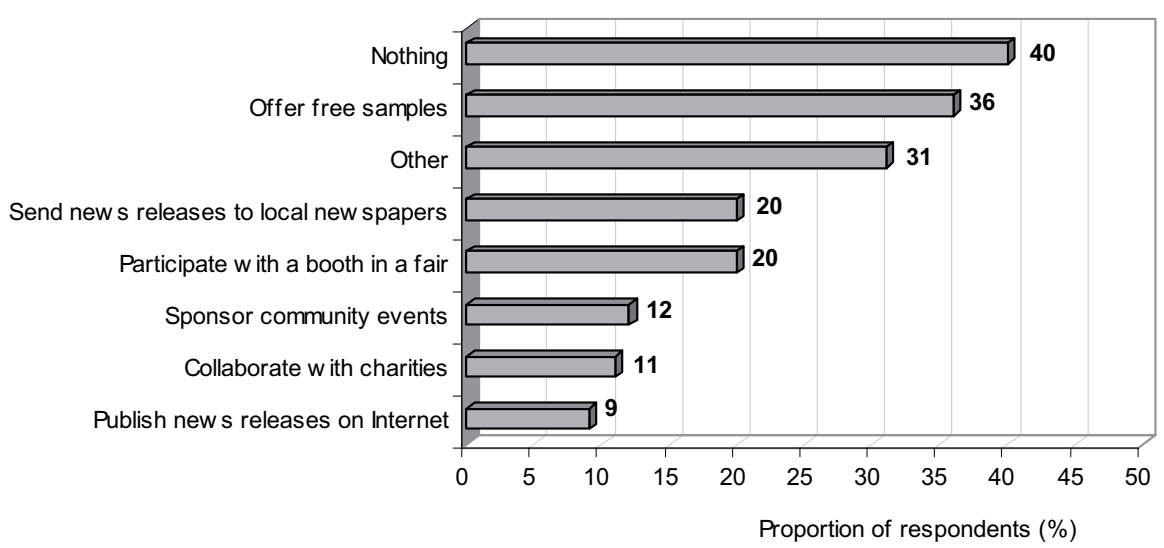

Fig. 5. Methods used by participants in a nationwide survey of U.S. chestnut producers to generate publicity and the proportion of respondents that use each method $(\mathrm{N}=90)$. Percentages do not add to 100 because respondents had the option to select more than one choice.

are economies of scale (minimum size requirements for profitable operations), high initial investments, cost advantages of existing players due to experience, scarcity of important resources, and long-term service contracts among existing players and their customers (Porter, 1980).

In Australia, the average cost to establish a 25 -acre chestnut orchard is $\$ 38,900$ (Trapnell et al., 1999). To enter the chestnut business, one can self-finance start-up costs without requiring loans or partnerships and establish at least a small-scale operation. All respondents (with only one exception) were self-financed to start their chestnut production business.

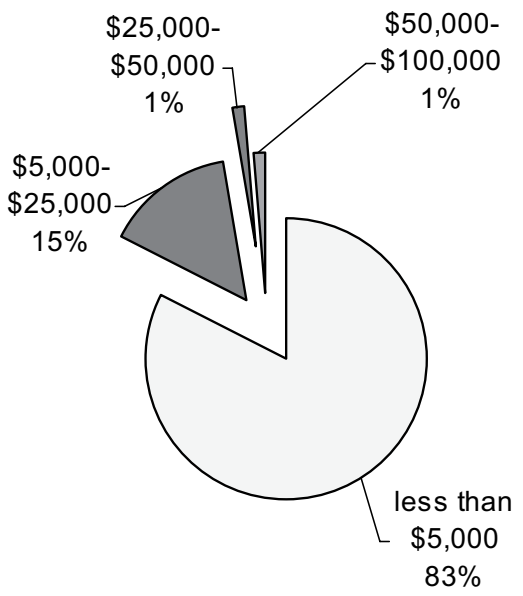

Fig. 6. Size of the business measured in annual gross sales for $76 \%$ of participants in a nationwide survey of U.S. chestnut producers who have not obtained a profit from the sale of chestnuts and chestnut products $(\mathbf{N}$ $=69$ ).
Additional investments are needed when production requires outside labor costs $(46 \%$ of respondents hire people for help, most of them seasonal or part-time for hand harvest, pruning, mowing, planting, and nursery help), refrigeration facilities $(81 \%$ of respondents refrigerate chestnuts after harvest), transportation (63\% of respondents use their own vehicle to transport chestnuts to the market), and marketing costs.

One negative aspect of starting a chestnut business is the time lag from initial investment to first return or profit. Out of our respondents, $41 \%$ obtained a return (had a first sale) in less than 5 years and $21 \%$ of respondents obtained the first return in 6 to 10 years, while $35 \%$ have yet to obtain a return. A large majority of respondents $(76 \%)$ are not yet profitable. Ten percent of respondents became profitable (revenues exceeded expenses) in 6 to 10 years; $7 \%$ in less than 5 years; and another $7 \%$ in 11 to 18 years. The factor that most influences the lack of profit is the size of the business $(83 \%$ of the respondents that are still unprofitable have less than $\$ 5000$ in annual sales from the chestnut business) (Fig. 6).

Production and marketing information and skills are critical resources to enter the market. However, responses to the survey confirmed the focus of respondents on production more than marketing, and the shortterm rather than long-term. Tools and equipment, production skills, and production information were valued higher than financial resources, market knowledge, and marketing skills, while labor availability and access to credit were valued least (Fig. 7).

Based on survey responses, individuals are attracted to the chestnut business by the potential for profit due to low initial investment and perceived market potential, or by interest in chestnuts and chestnut trees. At the same time, the lack of knowledge, information, available cultivars, and equipment; uncertainty of markets and demand; and the long time to obtain a return on investment are factors that

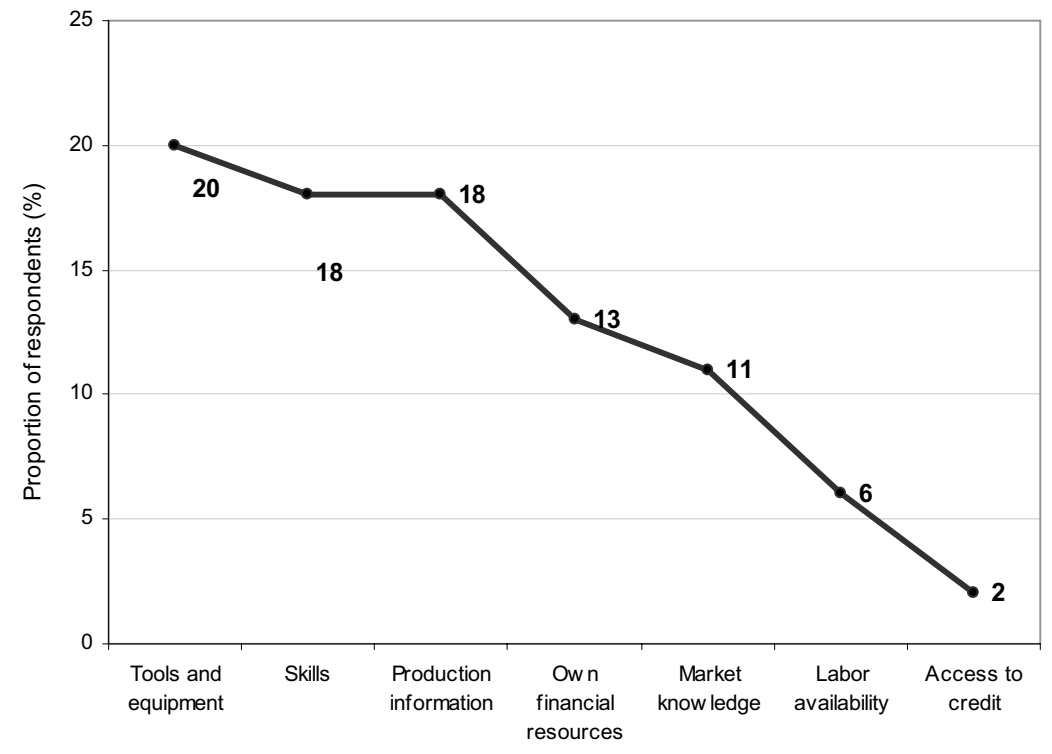

Fig. 7. Critical resources needed for a chestnut production business as identified by participants in a nationwide survey of U.S. chestnut producers $(N=90)$. Values represent percentage of respondents that ranked the critical resources 1 or 2 on a scale of 1 to 5 ( 1 being the most important and 5 the least important). 
deter people from starting a chestnut production business.

For the majority of respondents, commercial chestnut production is a recent development; faces many uncertainties; and the risk of failure in the market is high. Little research has been done on specific cultivars for each region, resistance to pests, and orchard management. Actual producers are learning as they go and continually experimenting.

MARKeT Force 2: Bargaining POWER OF SUPPLIERS. According to Porter (1980), supplier bargaining power is high when the market is dominated by a few large suppliers rather than by many fragmented sources of supply; when there are no substitutes for the particular input; and when switching costs from one supplier to another are high.

There are few major suppliers of grafted chestnuts in the industry. One particular nursery was mentioned as primary supplier by $31 \%$ of respondents, and other two nurseries were mentioned by $7 \%$ and $6 \%$, respectively. The rest of the respondents listed other sources of supply. An alternative to buying seedlings and cultivars is to produce them. Fifty-four percent of respondents produce their own seedlings and cultivars; $64 \%$ of respondents purchase grafted cultivars; $41 \%$ purchase seedlings; and $18 \%$ purchase seedlings and do their own grafting. of chestnut seedlings and cultivars, chestnut producers grow and graft their own trees. A few highly motivated chestnut producers are attempting to transform a cost of production into a revenue-generating activity by developing a nursery and selling seedlings and cultivars to other growers.

Market force 3: Bargaining POWER OF BUYERS. The bargaining power of buyers is high when they buy large volumes; there is a concentration of buyers; the product is undifferentiated and can be replaced by substitutes; customers are price-sensitive; and customers could produce the product themselves (Porter, 1980).

Consumers purchase chestnuts directly from farms, farmer markets, and retail locations, or online; or consume them in a prepared form in restaurants.

MARKET OUTLETS. The majority of respondents (63\%) sell their chestnuts locally (within a 75 -mile radius); $38 \%$
In the face of limited availability sell regionally (between 75 and 200 miles radius); and $21 \%$ sell nationally.

No major buyer was mentioned and no contractual arrangements exist between producers and their buyers. Many respondents (38\%) sell chestnuts on-farm. Thirty-four percent of respondents sell to farmers markets. Twenty-three percent sell fresh chestnuts to restaurants. Less than $20 \%$ sell to retail locations [e.g., ethnic stores (19\%), upscale grocery stores (18\%), health and natural food stores (17\%), national chain grocery stores $(11 \%)$, or wholesalers (12\%)] (Fig. 8). The small number of producer sales to grocery stores is expected, considering the nature of the industry. There is not enough production to satisfy the demands of quantity and continuity required by major grocery chains. Small-scale producers sell their products on-farm and online while largerscale producers have started to sell to other outlets.

Looking at the average prices (Fig. 9), the highest prices are paid by restaurants, followed by customers that buy online, health and natural food stores, farmers markets, and on-farm. Discount grocery stores, distributors, and wholesalers offer the lowest prices.

For most of the outlets, the range of prices is very large. Producers sell from $\$ 0.75$ to $\$ 6$ at farmers markets,

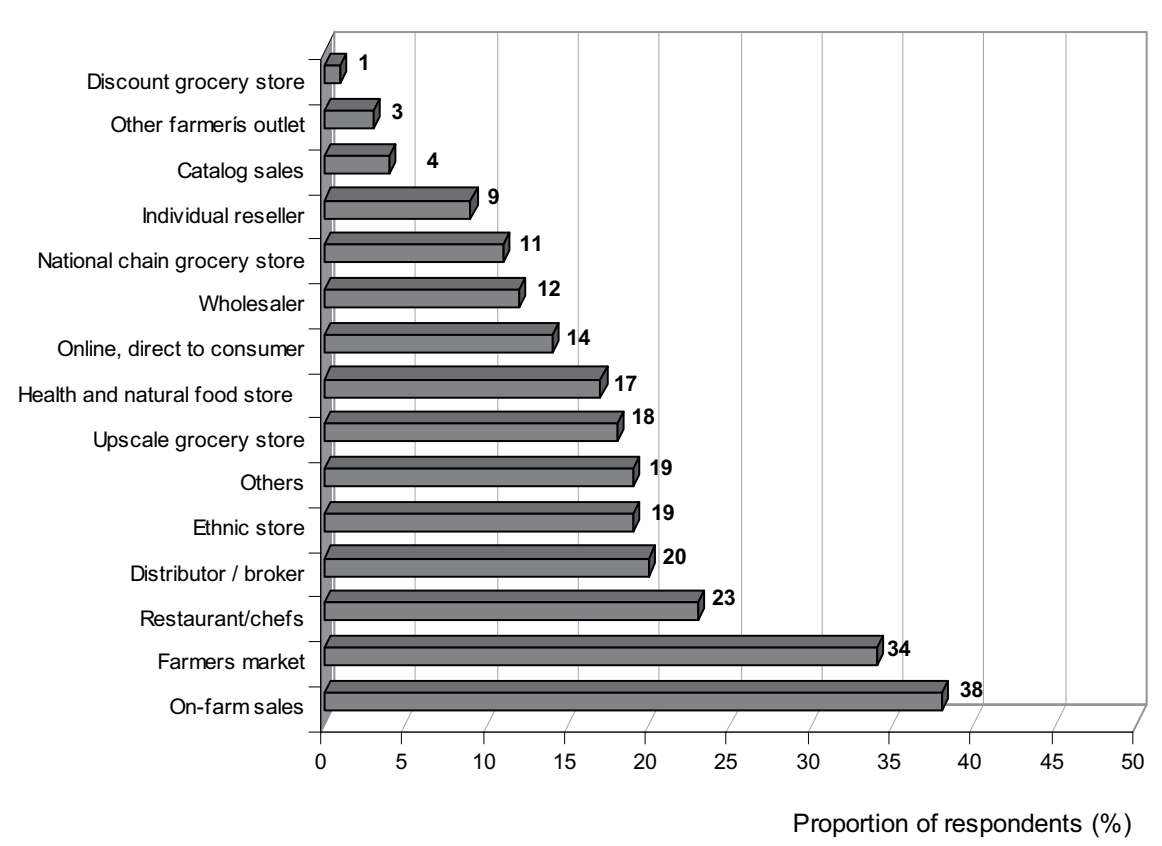

Fig. 8. Outlets for fresh chestnut sales used by participants in a nationwide survey of U.S. chestnut producers and the proportion of respondents that sell in each outlet $(\mathrm{N}=90)$. Percentages do not add to 100 because respondents had the option to select more than one choice.

$\$ 1.50$ to $\$ 6$ on-farm, or from $\$ 2$ to $\$ 7$ at restaurants (Fig. 9). In most cases, full-time farmers with farming operations focused on chestnuts receive higher selling prices. Further, producers who grow chestnuts from cultivars, grow organic chestnuts, and sell under a brand name obtain the highest prices.

A premium price was obtained for organic production. The average prices for almost all of the market outlets are higher for producers who sell only organic compared with the prices obtained by producers who sell pesticide-free and conventionally grown chestnuts (Fig. 10). Additionally, those who produce organic chestnuts sell more to upscale grocery stores, health and natural food stores, national chain grocery stores, and online, direct-toconsumer. Due to the large range of prices it is possible that the price can be increased by most of the producers without decreasing demand. To obtain higher prices, producers can switch to organic production and use branding, advertising, and publicity.

Respondents prefer to sell on-farm $(28 \%)$, followed by upscale grocery stores $(21 \%)$, farmers markets (17\%), and distributors (16\%) (Fig. 11).

Trends In DEMAND. The majority of respondents $(56 \%)$ indicated that demand for fresh chestnuts increased by $10 \%$ to $25 \%$ in the past 5 years. At
Hortlechnology • April-June 2006 16(2) 


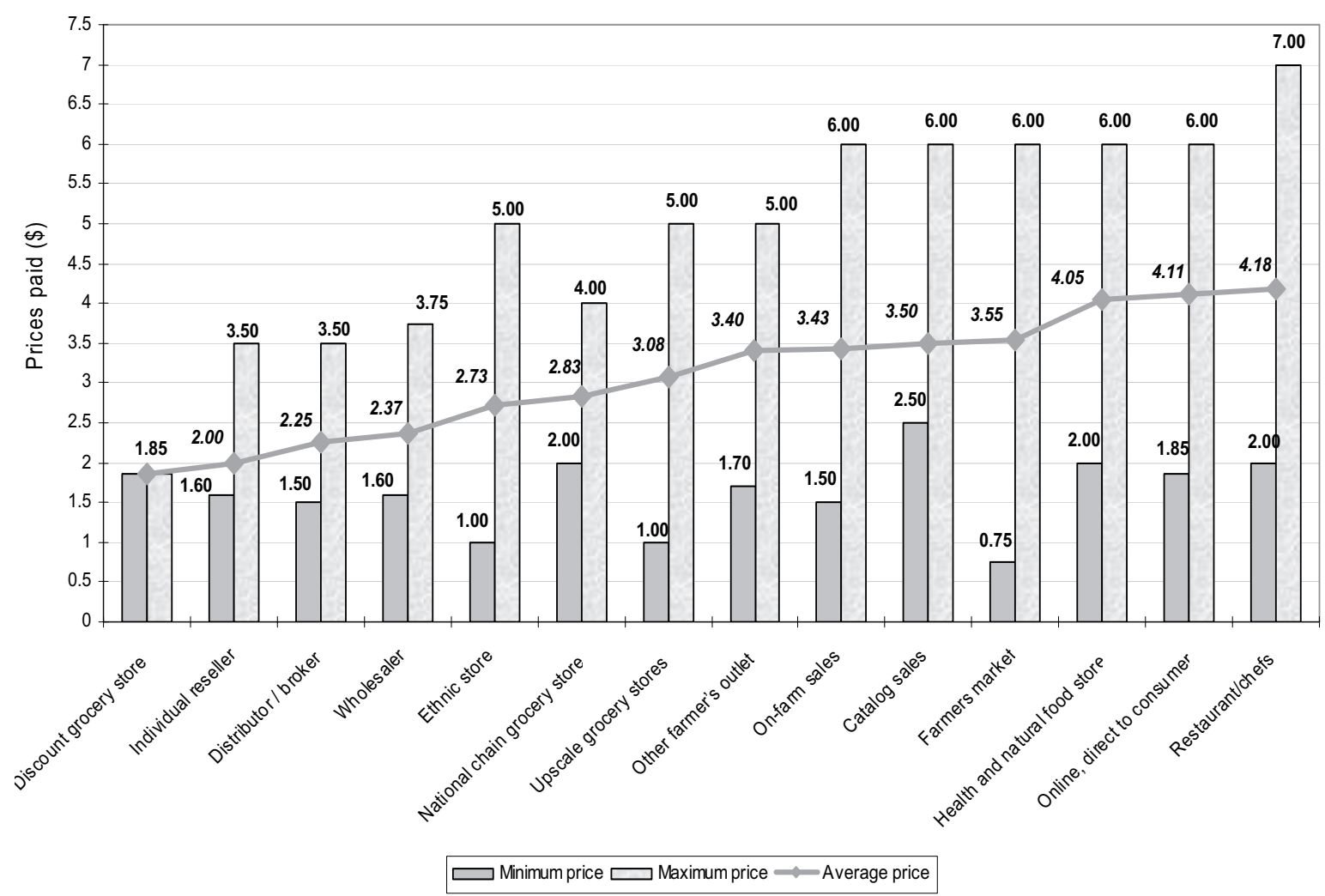

Fig. 9. Maximum, minimum and average prices paid by different buyers as identified by participants in a nationwide survey of U.S. chestnut producers $(\mathrm{N}=90)$

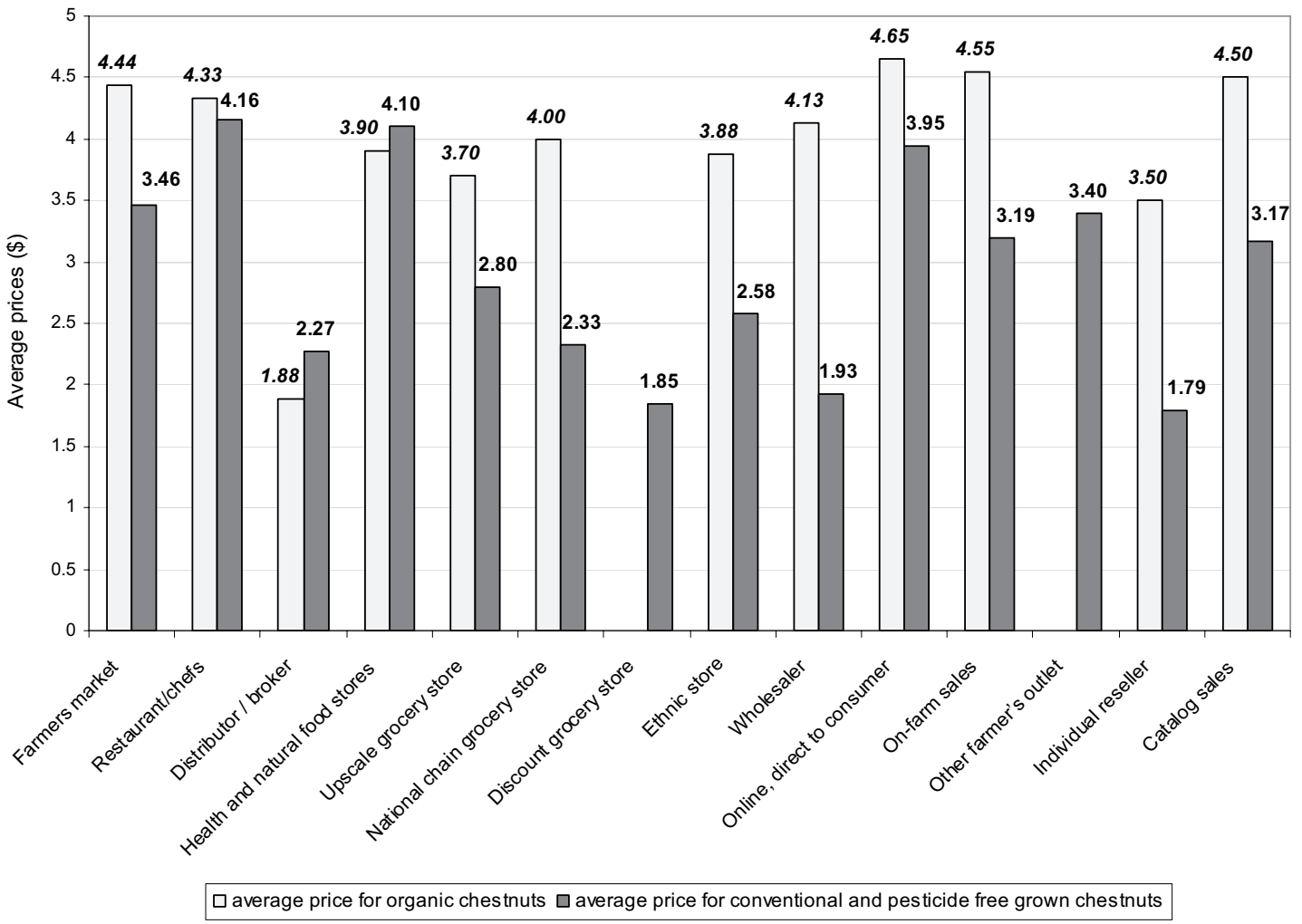

Fig. 10. Price premium (average price paid by different buyers for organic chestnuts compared with the average price for conventional and pesticide free grown chestnuts) obtained by surveyed U.S. chestnut producers for organic production ( $\mathrm{N}=$ 90). 


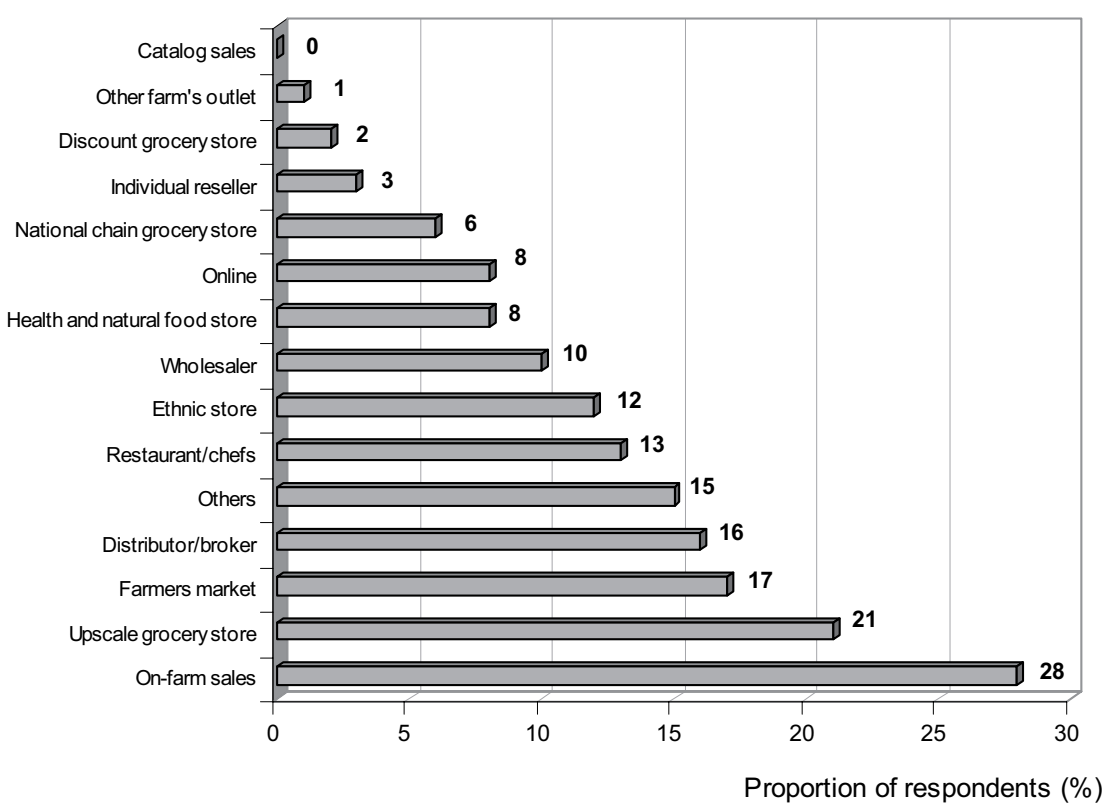

Fig. 11. Preferred buyers (ranked 1 or 2 on a 1 to 5 scale, 1 being the most preferred and 5 the least preferred) as identified by respondents to a nationwide survey of U.S. chestnut producers $(\mathrm{N}=90)$. Percentages do not add to 100 because respondents had the option to select more than one choice.

the present time, respondents stated that demand for fresh chestnuts is steady $(37 \%)$ or strong $(32 \%)$. A large number of respondents $(49 \%)$ believe that demand is in excess of supply, and $21 \%$ that demand is equal to supply, while $13 \%$ believe that demand is below supply. Demand for fresh chestnuts is expected to continue to increase by $10 \%$ to $25 \%$ in the next 5 years (62\% of respondents). Sixteen percent indicated demand will be stable, while only $1 \%$ felt that demand will decrease.

Due to the nature of the industry with its current focus on production of fresh chestnuts, few respondents expressed an opinion regarding demand for processed products.

There is little knowledge among buyers on how to handle chestnuts. Due to their high moisture content, chestnuts need to be cooled soon after harvest and kept refrigerated (to minimize water loss and decay). To ensure that chestnut quality remains high, $42 \%$ of respondents ship with information about perishability; $31 \%$ suggest the use of signs at the point of purchase; and the others hand out flyers or verbally communicate to the customer. In this way, producers seek to ensure that chestnut quality remains high and consumers will have a positive experience with chestnuts.

Market Force 4: Threat OF
SUBSTITUTE PRODUCTS. A threat of substitutes exists if there are alternative products with lower prices, better quality, nutritional benefits, and availability that can be used for the same purposes (Porter, 1980).

Most of the respondents $(70 \%)$ did not answer the questions related to substitutes. Out of all participants, $19 \%$ stated that chestnuts do not have substitutes, and a few respondents considered hazelnuts (Corylus avellana), pecans, almonds (Prunus dulcis), sweet potatoes (Ipomoea batatas), potatoes (Solanum tuberosum), rice (Oryza sativa), and oats (Avena sativa) as potential substitutes.

Nuts, grains, and even potatoes may be substituted for chestnuts, but chestnuts have unique characteristics. Chestnuts are almost fat free. High fiber content makes chestnuts a good snack food; the high percentage of complex carbohydrates are a source of energy. Chestnuts are also cholesterol free and contain a high amount of vitamin $\mathrm{C}$. Chestnut flour is gluten-free and useful for individuals who are affected by celiac disease (UMCA, 2004).

MARKeT FORCE 5: CoMpetitors, RIVALRY AMONG EXISTING FIRMS. This force describes the intensity of competition between existing businesses in the market. A rivalry can exist if there are many participants about the same size in the market or if there are low market growth rates. (Porter, 1980).

Given the size of the domestic market, the industry is too small to thoroughly evaluate domestic competition. Most respondents (69\%) declared that there are between one and 10 other chestnut producers in their area; 19\% are the only chestnut producers in their area. Forty percent of respondents felt that the number of chestnut farms remained stable in the past 5 years, while $31 \%$ noted an increase. Over the next 5 years, $54 \%$ think that the number of chestnut farms will remain stable, and $34 \%$, that they will increase. Since most producers are able to sell all of their production in a short amount of time, they feel unthreatened by competition in the short-run.

For new or existing producers, competition can arise not only from local producers, but also from imports. According to USDA statistics (2005), starting with 2001 , total value of imports was almost constant (\$11 million) but imports from China increased strongly (about $400 \%$ ). Only $8 \%$ of respondents consider that the import of fresh chestnuts would become a threat in the next 5 years. The attitude toward imports is probably based on the perception that domestic supply will be of better quality and can reach the market earlier. This creates an opportunity for local producers to increase production and replace imports.

Producers already in the market try to provide value to their customers to maintain or to increase their market share. To do this, producers build competitive advantages that help them differentiate their product from the competition. For our respondents, the most often declared competitive advantage was quality $(68 \%)$, followed by customer service (37\%), and market knowledge (20\%) (Fig. 12).

TrEnds In PRICE. Based on survey data, $37 \%$ of respondents indicated that the price of fresh chestnuts increased an average of $10 \%$ to $25 \%$ in the last 5 years or remained stable $(33 \%)$. In the next 5 years, $38 \%$ of respondents predicted that the price of fresh chestnuts will increase, while $24 \%$ of respondents believed that prices will remain stable.

Additional force: Policy. One federal policy considered by respondents to the survey as a threat to the profitability in the U.S. chestnut market 


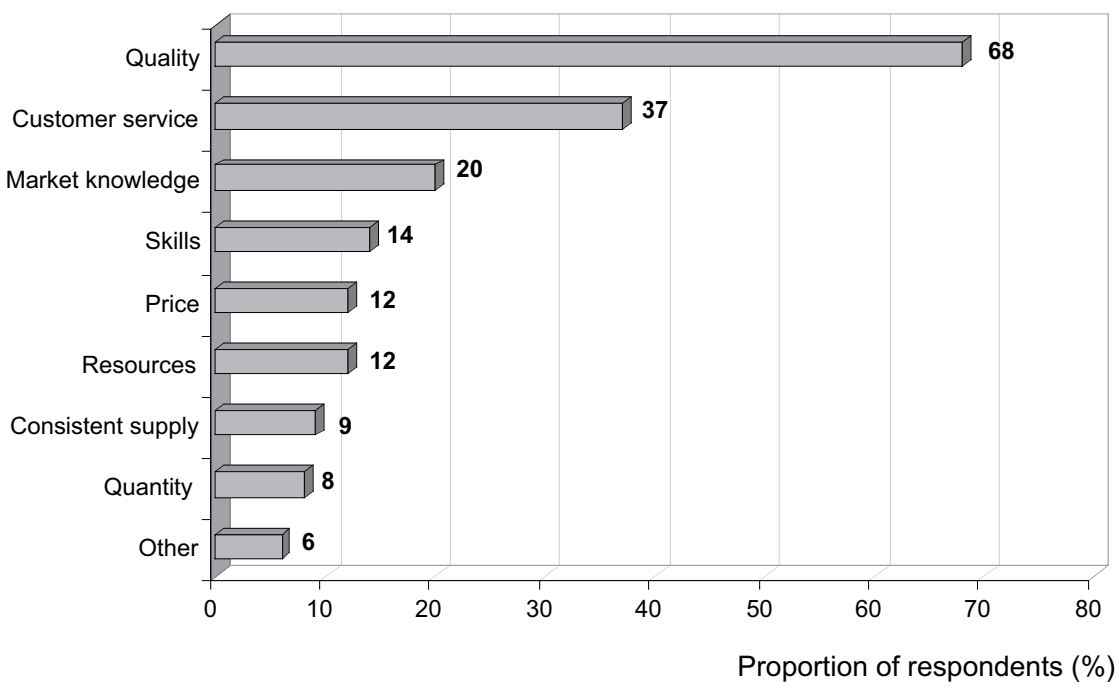

Fig. 12. Competitive advantages for successful domestic chestnut production business as identified by respondents in a nationwide survey of U.S. chestnut producers $(\mathrm{N}=90)$.

is the existence of trade agreements that allow subsidized chestnuts to enter into the U.S. The U.S. government through its Agency for International Development (USAID) is trying to assist food producers from less developed countries (e.g., Georgia) to compete in international food markets (USAID, 2003). Subsidizing the entry of lowcost chestnuts may impact the domestic chestnut producer who is struggling to overcome many barriers related to a minor crop.

Another policy mentioned was the quarantine restriction on importing potentially promising cultivars that are not available domestically. The shortage in domestic supply of certain cultivars coupled with the delay in testing and releasing new cultivars due to quarantine has the potential to adversely influence chestnut production.

Respondents mentioned an increase in regulations for agriculture that make it more difficult to grow chestnuts. An important aspect mentioned by some of the respondents in this respect was the lack of chemicals approved for minor crops as chestnuts. Growers can only experiment with different pesticides used for other nut species but do not have the assurance that they are using a registered product.

There were no policies identified as helpful to enter into the chestnut market. There are grants that may assist producers [e.g., USDA Sustainable Agriculture Research and Education (SARE) grants or the USDA Integrated
Organic Program], but none is specific for chestnuts.

\section{Conclusions and recommendations}

The U.S. chestnut industry is in its formative stages. The majority of chestnut producers have been in business less than 10 years. The volume of production is low (a majority of producers obtain less that $\$ 5000$ annually from the chestnut business and $35 \%$ have yet to have a first sale). U.S. chestnut producers are mainly part-timers or hobbyists. Only 20\% of respondents are full-time farmers and only two are $100 \%$ involved in the chestnut business. The size of production operations are small (50\% plant between 3 to 10 acres of chestnuts ) and are harvested manually. Trees are very young (46\% have trees younger than 10 years), barely entering commercial production. The majority of respondents sell only fresh chestnuts in bulk or packaged while a few respondents sell chestnut products.

Due to the limited size of commercial chestnut production within the U.S., PFFM provided only general information about the context of the industry. The information is valuable for businesses established in the market and for new producers that may consider entering the marketplace.

Chestnut production has many positive aspects. Chestnut cultivation can be a source of profit due to high demand, good prices, high volume of imports compared to domestic production, and relatively low initial investment requirements. Producing chestnuts can be a way to diversify an existing agricultural business. Chestnuts can be grown organically, have many nutritional and health benefits (e.g., gluten-free flour), and are associated with positive feelings, such as tradition, holiday, and family, that can help advertise the product.

One of the biggest barriers to success in the chestnut industry is the lack of information for producers, retailers, and consumers. For producers, there is a lack of expertise and experience with cultivars, orchard management, prices, markets, and distribution channels. There is little knowledge among buyers on how to handle chestnuts and increase shelf life. There is limited consumer awareness of the product (Gold et al., 2004b, 2005b). Another barrier is the 5 - to 10 -year time lag to get a return on investment. There is a shortage of available chestnut cultivar nursery stock for commercial production; the crop is perishable; there are problems related to pest and disease control; and the market is uncertain. Specific policies, such as existing quarantines for cultivars from other countries and lack of chemicals registered for use with chestnuts, can also be considered barriers to success.

In many cases, producers belong to growers associations. They learn from each other and together contribute to the development of the industry. By maintaining high quality and customer service, existing producers hope to successfully increase revenue and compete with imports.

Chestnut is still a minor crop in the U.S. and, because of that, not much attention is given to its development by federal or state agencies, universities, or other organizations. Chestnut growers associations must join their efforts to fund and support chestnut research and development of the industry. Both production and consumption of chestnuts can and should be stimulated. Efforts should be directed toward generating demand by increasing consumers' awareness about chestnuts, and by providing information and support to actual and future producers in order to generate enough domestic production to meet the created demand. Imports can be outcompeted by providing high quality, fresh, and timely products. 


\section{Literature cited}

Bassi, G. and J.H. Craddock. 1998. Performance and description of the introduced chestnut cultivar 'Colossal' in Cuneo Province, northwest Italy. Acta Hort. 494:317-318

Blisard, N., B-H. Lin, J. Cromartie, and N. Ballenger. 2002. America's changing appetite: Food consumption and spending to 2020 . U.S. Dept. Agr. Econ. Res. Serv., Food Rev. 25(1):2-9.

Bodet, L., T. Woods, and M. Ernst. 2001. The international marketing situation. Univ. Kentucky, Dept. Agr. Econ, AEC Staff Paper No. 411 .

Brereton and Company, Inc. 2002. The changing landscape of the food industry: Harvesting profit or pain? Food Ind. Rptr. Vol. 1. 12 Dec. 2005. <http://www. brereton.net/pdf/Food_Industry_Report.pdf $>$.

Food and Agriculture Organization of the United Nations. 2005. Global chestnut export. 12 Dec. 2005. <http://faostat.fao. org $/$ faostat $/$ servlet $/$ XteServlet3 ? Areas $=8$ $01 \&$ Items $=220 \&$ Elements $=91 \&$ Years $=20$ $03 \&$ Format $=$ Table $\&$ Xaxis $=$ Years $\&$ Yaxis $=C$ ountries \&Aggregate $=\&$ Calculate $=\& D$ Dom ain=SUA\&ItemTypes=Trade. CropsLivest ockProducts\&language $=\mathrm{EN}>$.

Fulbright, D.W. 2002. Growing chestnuts for commercial markets in Michigan and other midwest states: A pioneer industry. 12 Dec. 2005. <http://www.plantpathology. msu.edu/fulbright/Pages/MNPCpages/ growingchestnuts.html>.
Fulbright, D.W., M. Mandujano, B. Smith, and T. Kalchik. 2003. An overview of the emerging chestnut industry in Michigan. Annu. Rpt. Northern Nut Growers Assn. 94:9-13.

Gold, M.A., L.D. Godsey, and M.M. Cernusca. 2005a. Competitive market analysis of eastern red cedar. For. Prod. J. 55(12):58-65.

Gold, M.A., M.M. Cernusca, and L.D. Godsey. 2005b. Update on consumers' preferences for chestnuts. HortTechnology 15(4):904-906.

Gold, M.A., L.D. Godsey, and S.J. Josiah. 2004a. Markets and marketing strategy for agroforestry specialty products in North America. Agrofor. Systems 61:371-382.

Gold, M.A., M.M. Cernusca, and L.D. Godsey. 2004b. Consumer preferences for chestnuts, eastern black walnuts, and pecans. HortTechnologyl4(4):583-589.

Haak, R.A. and S.K. Haak. 2003. Growth and production of several chestnut cultivars growing on a Michigan chestnut farm: Production for 2001 to 2003. Annu. Rpt. Northern Nut Growers Assn. 94:14-17.

Hunt, K., M.A. Gold, W. Reid, and M.Warmund. 2005. Growing chinese chestnuts in Missouri. Agroforestry in action. Univ. of Missouri Ctr. for Agrofor. 23 Jan. 2006. <http://www.centerforagroforestry.org/pubs/chestnut.pdf>.

Kelley, K.M. and B.K. Behe 2002. Chefs' perceptions and uses of 'Colossal' chestnuts. HortTechnology 12(1):172.

Porter, M.E. 1980. Competitive strategy: Techniques for analyzing industries and competitors. Free Press, New York.
Trapnell, L., S. Carmichael, and D. Ridley 1999. Chestnut economics: Profitability and cash flow from chestnuts, p. 3.1-3.5. In: D. Ridley and J. Beaumont (eds.). The Australian chestnut growers' resource manual. Dept. Natural Resources and Environ., Agr. Victoria, Inst. Hort. Dev., Knoxfield, Australia.

University of Missouri Center for Agroforestry. 2004. Why chestnuts: Nutrition and your health. Univ. of Missouri Ctr. for Agrofor. 23 Jan. 2006. <http://www.centerforagroforestry.org/pubs/whychestnuts.pdf>.

U.S. Agency for International Development. 2003. Georgian chestnuts crack elite European market. Front lines. 11. 12 Dec. 2005. <http://www.usaid.gov/ our_work/global_partnerships/gda/ showcase/Nov03_FrontLines.pdf>.

U.S. Dept. of Agriculture. 2005. U.S. trade imports. Fatus commodity aggregations. Chestnuts. U.S. Dept. Agr., Foreign Agr. Serv. 12 Dec. 2005. <http://www.fas.usda. gov/ustrade/USTImFatus.asp?QI=>.

Wahl, T. 2002a. Southeast Iowa Nut Growers Cooperative. Chestnut market opportunities: Assessing upscale restaurant interest in value added chestnut products. Food Processing Ctr, Inst. Agr. and Natural Resources. Univ. of Nebraska, Lincoln.

Wahl, T. 2002b. The chestnut grower's primer. Southeast Iowa Nut Growers. 1st ed. 12 Dec. 2005 . <http://www.pfi.iastate. edu/ofr/The_Chestnut_Primer_2002. pdf>. 